University of Miami Law School

Institutional Repository

University of Miami Inter-American Law Review

$1-1-2006$

\title{
Public Sector Corruption in Mexico: Social Representations Among the Legal Community of the Federal District
}

José C. García González

Rosa O. González Robles

Adolfo Mir Araujo

Araceli García del Soto

Follow this and additional works at: http://repository.law.miami.edu/umialr

\section{Recommended Citation}

José C. García González, Rosa O. González Robles, Adolfo Mir Araujo, and Araceli García del Soto, Public Sector Corruption in Mexico: Social Representations Among the Legal Community of the Federal District, 37 U. Miami Inter-Am. L. Rev. 231 (2006)

Available at: http://repository.law.miami.edu/umialr/vol37/iss2/2 


\title{
ARTICLES
}

\section{Public Sector Corruption in Mexico: Social Representations Among the Legal Community of the Federal District}

\author{
José C. García González, \\ Rosa O. González Robles, \\ Adolfo Mir Araujo, \\ and \\ Araceli Garcia del Soto*
}

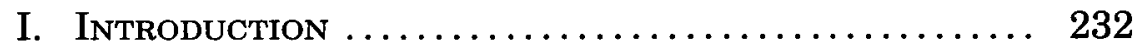

II. Towards a Single Concept of Public Corruption and an Explanation of Its Causes ............. 233

* José Cruz García González has a law degree from La Salle University in Mexico City. He also holds a Masters degree in Latin American Studies, an Advanced Studies Diploma in Criminal Law, and is presently finishing his Ph.D. thesis in Criminal Law, all from the University of Salamanca in Spain. Prior to his current Ph.D. studies, he was a criminal lawyer in Mexico City. He has also worked as an intern for the United Nations Center for International Crime Prevention in Vienna Austria, as an advisor on legal issues for UNIDO and as an executive in an international law firm based in Madrid. Rosa Obdulia González Robles holds a Masters degree in statistics from the University of Chapingo in Mexico. Since 1978, she has been a research professor for the Autonomous Metropolitan University in Mexico City, were she has co-authored many national and international statistics articles in diverse subject areas, such as biology, biotechnology, education and sociology. Adolfo Mir Araujo holds a law degree from the National Autonomous University of Mexico and a Ph.D. in sociology from the University of Texas in Austin. Since 1974, he has been a research professor for the Autonomous Metropolitan University in Mexico City and has published numerous national and international academic articles. Araceli Garcia del Soto received her Masters degree in Social Sciences from the Juan March Foundation in Madrid and a Ph.D. in Sociology from the University of Salamanca in Spain. She is currently the Director of Refugee Initiatives at the Solomon Asch Center for the Study of Ethno-political Conflict at the University of Pennsylvania and is a member of the International Psychosocial Working Group. She has taught at various Spanish universities in such areas as social structure, methods for social analysis and human rights, and has published and lectured in Europe, Sri Lanka, Africa and the United States on psychosocial interventions with survivors of violence. She has collaborated with local and international non-governmental organizations for over a decade, formulating programs for different funding agencies and implementing psychosocial and community programs with survivors of violence in four continents. The authors would like to express their most sincere thanks to Juan Carlos Ferrao and Carlos Palavicini for their invaluable support in carrying out the surveys that provided the basis for this study. 


\section{The Mexican Situation in the Current}

INTERNATIONAL CONTEXT AND THE INFLUENCE OF THE Political System on the Spread of The

Corruption Phenomenon ................... 235

IV. Social Representations of Public Corruption in Mexico ............................. 242

A. Preface to the Study ................... 242

B. Analysis of the Study .................... 243

V. Proposed Strategy to Fight Corruption ........ 255

A. Consistently Sanction Transgressors .......... 256

B. Involve Civil Society in the Diagnosis of Corrupt Systems........................... 256

C. Concentrate Prevention by Repairing Corrupt Systems............................... 257

D. Provide Incentives for Reform ............. 257

E. Strengthen International Cooperation Against

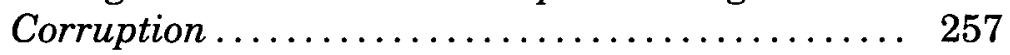

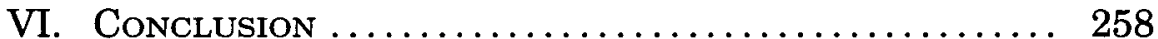

\section{INTRODUCTION}

Historically, the judgment of many public officials in Mexico has been influenced by private interests, leading these officials (and, consequently, the state) to make erroneous decisions in order to maintain their preferential and privileged status above ordinary citizens rather than serving public needs. This is not to suggest that corruption is absent from the private or business sectors, nor that corruption at both the international and the national levels does not pose an equally serious problem for the country. ${ }^{1}$ In fact, in some instances, private sector corruption can actually prove far more damaging than its political/administrative counterpart because it can go unnoticed by the general public, whereas the public sector is more closely monitored due to the nature of its functions. ${ }^{2}$

1. See Napoleon Saltos Galarza, Etica y Corrupcion: Estudio De Casos 44 (2001) (citing Jaime Zuluaga Nieto, Cuando la Corrupción Invade al Tejido Social, Nueva Sociedad (Venez.), Sept.-Oct. 1996, at 148-159), available at http:// www.respondanet.com/spanish/anti_corrupcion/informes/ capitulo2_saltos_galarza.pdf (defining and detailing private corruption).

2. It cannot be forgotten that in all cases where bribery is related to government acquisitions, a private agent will also be involved, offering, promising or granting any benefit in return for an unwarranted advantage in his business dealings with the state. Robert Klitgaard, Democracia y Mercados Libres, Recursos Eficaces Contra la Corrupción, Oct. 4, 2001, http://www.respondanet.com/spanish/anti_corrupcion/ publicaciones/articulos/corrupcion_promocion.htm. 
This article sets out primarily to study the phenomenon of public corruption in Mexico and the social perceptions of this problem among a specific section of Mexican society. To this end, it first draws up a theoretical framework of the issue, describing the main trends that define the phenomenon and explain its causes. It then studies the Mexican situation within the current international context, outlining the structural features of the Mexican political system and the way in which they are closely interlinked with widespread public corruption across the country. Lastly, this article examines the results of a survey-based study of the different social representations of the phenomenon among law students and professionals in México City.

\section{Towards a Single Concept of Public Corruption and an Explanation of Its Causes}

Corruption is a pathology as ancient as the first civilizations. It has appeared throughout the ages and across all cultures, varying in form and intensity. For instance, Hammurabi's Code "regulated the conduct of public officials" long before the emergence of the modern state. ${ }^{3}$ More than thirteen centuries later, Aristotle identified three types of government or political regimes (together with their three respective deviations or forms of corruption) in his study on politics: kingship, aristocracy and timocracy (also referred to as a polity). ${ }^{4}$ Within this context and in particular, he highlighted tyranny as the deviation or corruption of the kingship, declaring that, "though both are monarchies, they show the widest difference, since the tyrant considers his own advantage, but the king considers the advantage of his subjects."

Carl Friedrich insinuates that Aristotle's description of tyranny as a corrupt form of monarchy derives from the same basic principles as the concept of corruption applicable in modern times to the public official who, against the conventions of routine conduct, secretly accepts a bribe to sway his or her decision on a matter. ${ }^{6}$ However, given the general nature of such a doctrine, finding an accepted definition is complicated by the fact that present-day

3. Elvira María Restrepo de Johnson, Conceptualizacion de la Corrupcion Politica, in La Corrupcion en Colombia 23 (Fernando Cepeda Ulloa ed., 1997).

4. Aristotle, Nichomachean Ethics 130 (Terence Irwin trans., Hackett Publ'g Co. 2d ed. 1999).

5. Id.

6. See Carl J.Friedrich, Corruption Concepts in Historical Perspective, in Political Corruption: Concepts \& Contexts 15, 15 (Arnold J. Heidenheimer \& Michael Johnston eds., 3d ed. 2002) (defining corruption merely as "deviant behavior 
corruption is not legally defined or typified in many penal codes, but rather constitutes a pre-legal term used primarily in the social sciences. ${ }^{7}$ At the same time, the multidimensional nature of the concept itself also creates a broad range of perspectives across disciplines and among professionals in various social sciences fields ${ }^{8}$ (political scientists, sociologists, criminologists, civil servants/ organizations, ${ }^{9}$ economists, ${ }^{10}$ public interest professionals, ${ }^{11}$ etc). For the purposes of this article, concepts within the many existing perspectives and relating to the scope of civil service activities will serve as our point of departure, defining as corrupt "a public official who makes use of his power for an illegal purpose, motivated by the desire to achieve private advantage." 12

The debate on the possible causes underlying the emergence and spread of this social pathology has been equally intense, with emphasis on structural interpretations by analysts who believe that corruption is simply a manifest sign of the defects or imbalances in social organization itself..$^{13}$ Moreover, they consider it to be the result of the processes of modernization, economic inequality, poverty and forms of political dominance. ${ }^{14}$ Another camp argues that a combination of these causes and a series of cultural

associated with a particular motivation, namely that of private gain at public expense").

7. See, e.g. Agnieszka Klich, Bribery in Economies in Transition: The Foreign Corrupt Practices Act, 32 STAN. J. INT'L L. 121, 133 n.63 (stating that the Russian criminal code does not define the term "corruption").

8. See Francisco M. Suarez, La Multidimensionalidad del Concepto de Corrupcion (1999), http://www.econ.uba.ar/www/institutos/admin/ceo/simposio99/ suarez.htm.

9. See Francisco J. Laporta \& Silvina Alvarez, La Corrupcion Politica 20 (1992); Stephen D. Morris, Corruption and the Mexican Political System: Continuity and Change, ThIRD World Quarterly, Vol. 20, No. 3, 1999, at 623, 626-627 [hereinafter Morris, Continuity and Change], reprinted in CoRRuptIon IN THE Developing World 102, 105-106 (Robert Williams \& Robin Theobald eds., Edward Elgar Pub. 2000); Eduardo A. Fabián Caparrós, La Corrupcion: Aspectos JuRfDICOS Y Economicos 17 (2000).

10. See generally Jacob Van Klaveren, The Concept of Corruption, in Political CoRRuption: A HANDBOOK 25-28 (Arnold J. Heidenheimer, Michael Johnston \& Victor T. LeVine eds., 1989).

11. See generally Political CoRruption: Concepts \& Contexts, supra note 6 , at 3-14; Carl J. Friedrich, Corruption Concepts in Historical Perspective, in Political CoRruption: ConCEPTS \& ConTEXTs, supra note 6, at 15-23.

12. CAPARRós, supra note 9 , at 17 (translation by authors).

13. See, e.g., Samuel P. Huntington, Modernization and Corruption, in Political CoRruption: Concepts \& ConteXts, supra note 6, at 262 ("Corruption varies inversely with political organization .... Corruption is most prevalent in states which lack effective political parties, in societies where interests of the individual, the family, the clique, or the clan predominate.").

14. See generally James C. Scott, Corruption, Machine Politics and Political 
conditions have favored its emergence, ${ }^{15}$ an approach which finds resonance with those who structure their interpretations around market and economic theories. ${ }^{16}$ However, depending on the seriousness and extent of the problem in a given country, it is possible that more than one of these hypotheses offers a logical explanation.

\section{The Mexican Situation In the CurRent INTERNATIONAL CONTEXT AND THE INFLUENCE OF the Political System on the Spread of the Corruption Phenomenon}

The non-governmental organization Transparency International (TI) produces the most comprehensive and recognized Corruption Perceptions Index (CPI) in the international sphere. Since changes in the levels of corruption of a country evolve slowly, TI decided to base the CPI on a three-year average. ${ }^{17}$ Therefore, the CPI for the year 2004 is based on surveys and polls provided between 2002 and 2004, classifying a record number of 146 countries. ${ }^{18}$ The CPI gives each country a score corresponding to its relative level of corruption. These scores have a range between zero and ten - the lower the number, the more corrupt the country. ${ }^{19}$ The countries are then ranked, based on their score, in order from least to most corrupt. ${ }^{20}$ For example, Mexico is tied for the 64th position in the index with a score of 3.6, which basically represents the middle of the pack for Latin American countries. $^{21}$ Other Latin American countries appear in the index as follows: Chile (score: 7.4, rank: 20th), Uruguay (score: 6.2, rank: 28th), Costa Rica (score: 4.9, rank: 41st), El Salvador (score: 4.2,

Change, in Political Corruption: Concepts \& Contexts, supra note 6, at 221-231; Huntington, supra note 13, at 253-263.

15. See Sandro Garcia Rojas Castillo, IX Congreso Internacional del CLAD sobre la Reforma del Estado y de la Administración Pública, La lucha Contra la Corrupción en México: la Reforma Integral en Materia de Justicia en el Marco Jurfdico Mexicano Frente al Reto de la Lucha Anticorrupcion 3 (2004), available at $\mathrm{http} / / \mathrm{www}$.clad.org.ve/fulltext/0049908.pdf.

16. See, e.g., Klaveren, supra note 10.

17. Transparency Int'l, a Short Methodology Note: Transparency International Corruption Perceptions InDEX (CPI) 2004 (2004), http:// www.transparency.org/content/download/1535/7980/file/method_note_en.pdf.

18. Id.

19. Transparency Int'l, Corruption Perceptions Index (2004), available at http://www.transparency.org/policy_and_research/surveys_indices/cpi/2004.

20. See id.

21. Id. 
rank: tied for 51st), Brazil (score: 3.9, rank: 59th), Belize (score: 3.8, rank: tied for 60th), Colombia (score: 3.8, rank: tied for 60th), Cuba (score: 3.7, rank: tied for 62nd) and Panama (score: 3.7, rank: tied for 62nd), Peru (score: 3.5, rank: tied for 67th), the Dominican Republic (score: 2.9, rank: tied for 87th), Argentina (score: 2.5, rank: tied for 108th), Ecuador (score: 2.4, rank: tied for 112th), Honduras (score: 2.3, rank: tied for 114th), Venezuela (score: 2.3, rank: tied for 114th), Bolivia (score: 2.2, rank: tied for 122nd), Guatemala (score: 2.2, rank: tied for 122nd) and Paraguay (score: 1.9 , rank: tied for 140 th). ${ }^{22}$

In October 2001, the organization Transparencia Mexicana published the results of a survey assessing the level of corruption in each state in Mexico. The results revealed that Mexico City, referred to occasionally in this article (and in the Mexican vernacular) as the Federal District, ranked as the most corrupt state in the country - it was reported that $22.62 \%$ of applications made by citizens were accompanied by bribes, or "mordidas," as they are commonly called, to the responsible authorities in order to obtain the respective service requested. ${ }^{23}$ A second survey, conducted in 2003, showed the level of corruption dropped little, with Mexico City ranked second among the country's most corrupt states. ${ }^{24}$ It is currently estimated that the country loses $9.5 \%$ of its Gross Domestic Product due to corruption, ${ }^{25}$ and that 23 billion pesos, or approximately US $\$ 2.3$ billion, are spent yearly on "mordidas" alone. ${ }^{26}$

22. Id.

23. Transparencia Mexicana, Encuesta Nacional de Corrupción y Buen Gobierno 2001. Índice de Corrupción y Buen Gobierno por EnTIDAD Federativa (2001), available at http://www.transparenciamexicana.org.mx/ENCBG/\#encbg2001 (download the relevant PDF file); see also Transparencia Mexicana, Encuesta Nacional DE CoRrupción y Buen Gobierno 200114 (2001), available at http:// www.transparenciamexicana.org.mx/ENCBG/\#encbg2001 (download the relevant PDF file).

24. Transparencia Mexicana, Encuesta Nacional de Corrupción y Buen Gobierno 2003. Índice de Corrupción y Buen Gobierno por Entidad Federativa (2003), available at http://www.transparenciamexicana.org.mx/ENCBG/\#encbg2003; see also Transparencia Mexicana, Encuesta Nacional de Corrupcion y Buen GoBIERNo 20034 (2003), available at http://www.transparenciamexicana.org.mx/ ENCBG/\#encbg2001 (download the relevant PDF file).

25. CASTILlo, supra note 15 , at 6 . "This figure equates to [US] $\$ 54.1$ billion, which is roughly equal to $37.6 \%$ of Government expenditures for $2001,37.1 \%$ of national banking shares, [and] $33.7 \%$ of national foreign debt . . . . This percentage is significant when taking into account that education accounts for the greatest single expenditure of the Mexican Government at just 6\% of [Gross Domestic Product]." Id. at $6 \mathrm{n} .24$ (citation omitted).

26. Id. at 6. 
The quest for a clear account of public corruption in Mexico is a difficult task, given the complexity of its causes and, therefore, of its solution. Some analysts "blame the system of favors and patronage that flourished in pre-Hispanic times . . ."27 Others with stronger leanings towards nationalism argue that corruption was imported from Spain, noting in particular that the conquistadors saw Mexico merely as a pillaging ground. ${ }^{28}$ However, independence failed to bring about any great change in the customs of the ruling class as later governments were placed in the hands of camarillas, factions seeking personal or class advancement. ${ }^{29}$

Alan Riding, a former bureau chief for The New York Times in Latin America, claimed in the middle of the 1980s that the Mexican political system had never existed without corruption, and that it was essential for it to function and survive, serving as the "oil' that makes the wheels of the bureaucratic machine turn and the 'glue' that seals political alliances." ${ }^{30}$ However, Stephen D. Morris, political science professor at University of South Alabama, asserts that corruption in Mexico "emanates from a structural imbalance between State and social forces, which actually affords the Mexican State and its representatives a virtual monopoly over opportunities for wealth and mobility." ${ }^{11}$ In turn, this absolute concentration of power creates favorable conditions for widespread political corruption. Morris therefore stressed that corruption had not simply been a single attribute of the Mexican political system, but, in actuality, corruption was the Mexican political system. $^{32}$

A number of circumstances have led the political system in Mexico to attract considerable attention at the international level. Because, for much of its modern history (nearly seventy years), it has been almost entirely dominated by a single political regime, the Institutional Revolutionary Party (PRI), Mexico has been able to achieve a level of stability and dominance of civil government unequaled by any other Latin American state for such a long period of time. ${ }^{33}$ The structural features that have characterized

27. Alan Riding, Distant Neighbors: A Portrait of the Mexicans 113 (1985).

28. Id. at 114.

29. Id.

30. Id.

31. Stephen D. Morris, Corrupción Polftica en el México Contemporaneo 63 (1992) [hereinafter MORRIS, CORRUPCION POLfTICA] (translation by authors).

32. Morris, Continuity and Change, supra note 9, at 102.

33. See Roderic Ai Camp, Politics in Mexico: The Decline of Authoritarianism 67, 174-75 (3d ed. 1999) (detailing, respectively, (1) PRI presidents beginning in 1934, and (2) the PRI's recent political victories as well as its ability to adapt). 
the political system over the years, distinguishing it from other similar systems, are as follows: authoritarianism, clientelism, corporatism and presidentialism. ${ }^{34}$

The Mexican system might be described most simply as authoritarian..$^{35}$ But this characterization is somewhat misleading: Mexico is in no way comparable with true authoritarian countries, such as Cuba, China and the former Soviet Union. ${ }^{36}$ It is best described as a "semi-authoritarian" political system. ${ }^{37}$ Roderic Ai Camp, professor of government at Claremont McKenna College, describes it as a "hybrid of political liberalism and authoritarianism," and, from the mid-1990s, as a "system in transition," with past practices thriving alongside the great challenges yet ahead. ${ }^{38}$

Practices of clientelism, another structural feature of the Mexican political system, present an additional factor that for years helped the government to maintain power and stability. ${ }^{39}$ The Mexican ruling class used the state party to build a paternalistic hierarchy within which its highest profile members were in charge of distributing benefits such as public posts, money and any type of asset to the lower members of the hierarchy, receiving their loyalty and faithfulness in return. ${ }^{40}$ Possibly the most telling aspect of clientelism regarding its recruitment of the privileged is "the political clique, the camarilla."41 A camarilla can be defined as "a group of persons who share political interests, and rely on one another to improve their chances in the political leadership."42 These camarillas have "determined, more than any other variable discussed, who goes to the top of the political ladder, what paths are taken, and the specific posts they are assigned." ${ }^{\text {O3 }}$ Over the years, Mexican political culture has predisposed its political system to a dependency on the existence of these camarillas. ${ }^{44}$

Present throughout Latin American countries, corporatism,

34. See id. at 8-13; see generally Mario Caciagli, Clientelismo, Corrupcion y Criminalidad Organizada (1996); see also infra notes 34-64 and accompanying text.

35. CAMP, supra note 32 , at 9.

36. Id.

37. Id.

38. $I d$.

39. Caciagli, supra note 33 , at 18 . "Clientelism can be defined as a dyadic relationship, whereby a person of higher status, the patron, uses his influence and resources to facilitate the protection and benefits afforded to a person of lesser status, the client, who offers services and/or support." Id. (translation by authors).

40. Id.

41. CAMP, supra note 32 , at 116.

42. Id.

43. Id.

44. Id. 
the third structural feature of the Mexican political system, was established in the 1930s, largely during the presidency of General Lazaro Cardenas, who was in power from 1934 to $1940 .{ }^{45}$ Corporatism implies a corporate relationship between the state and key social or interest groups. ${ }^{46}$ In this way, the government placed itself in an advantageous position, representing the most conflicting of social interests while simultaneously acting as arbiter of the most diverse social needs. ${ }^{47}$ The largest and most important interest groups were absorbed by the PRI, thereby acquiring legitimacy and a key role in matters of both the party and the country. ${ }^{48}$ The PRI could not therefore be conceptualized simply as a conventional political party, being at once "a political, economic and social system." 49

The fourth structural feature, presidentialism, is "the centralization of authority in the executive branch." ${ }^{50}$ The formal powers of the President derive from the Constitution, ${ }^{51}$ but until only recently a spectrum of informal or meta-constitutional powers existed within the system, giving the President the ability to: 1) amend the Constitution, 2) designate a successor and 3) designate or remove the majority of public posts including those of governors and legislators. ${ }^{52}$ Appointing positions, including personal successors, from among friends or family members is a practice known as "dedazo." ${ }^{33}$ It was dedazo, more than any other meta-constitutional power, that permitted the hegemony of the executive over the PRI and the other constitutional powers for so many years. ${ }^{54}$ There can be no doubt, too, that such connections lead to increased wealth of presidents, their relatives and their friends. ${ }^{55}$

45. Id. at 10 .

46. Id.

47. $I d$.

48. Id.

49. Manuel Alcantara Sáez, Sistemas Politicos de America latina: Volumen II: México, América Central y el Caribe 60 (1999) (translation by authors).

50. CAMP, supra note 32, at 11.

51. Carole J. Wilson, Presidential Influence on Public Opinion in Mexico 3 (1998), available at http://136.142.158.105/LASA98/Wilson.pdf.

52. Id. at 3-4.

53. See Javier Livas, The Mexican Election System As a Violation of International Human Rights Law, 16 Loy. L.A. INT'L \& CoMP. L. REv. 373, 379 n.6 (1994) (defining dedazo as "a colloquial expression for the process whereby the President handpicks individuals for key political positions").

54. See Luis Carlos Ugalde, The Transformation of Mexican Presidentialism, 1929-2000, 25 Fletcher F. World AFF. 115, 120 (2001).

55. See, e.g., Andrés Oppenheimer, OJos Vendados: Estados Unidos Y EL Negocio de la Corrupción en América latina 240-241, 254-273 (2d ed. 2001) 
Although Mexico has always been able to rely on opposition political parties, no one from these parties had occupied significant government positions until $1988 .^{56}$ In 1988 , Cuauhtémoc Cárdenas led the most successful opposition presidential campaign known to date, losing the elections amidst turmoil and rumors of vote-rigging..$^{57}$ Despite the official result, it was increasingly recognized, from 1988 onwards (if not earlier), that the traditional dominance of the PRI as a hegemonic party was no longer invincible in the country. ${ }^{58}$

Seeking on the one hand to lend his government credibility, and on the other to mollify the opposition, former President [Carlos Salinas (1988-1994)] increased the opportunities for opposition politicians to assume power both at the local and state levels. This strategy mainly benefited the National Action Party (PAN), whose free market economic policies closely resembled those of the technocratic group in power. . . . Former President Salinas' six-year term ended when he stepped down from his post, accused in the public eye of having created one of the most corrupt governments in the history of modern-day Mexico and of abusing public power for private gain, for that of this family and of those close to him during his mandate, as well as leaving the country bankrupt. ${ }^{59}$

President Ernesto Zedillo (1994-2000) constantly reaffirmed the Republican presidency, leaving decisions in the hands of Congress or local competent authorities that in other eras were controlled from Los Pinos (the President's official residence). ${ }^{60} \mathrm{He}$ renounced the power to name his successor, which to a large extent was a transcendental factor without which the process of transition to democracy in 2000 could not have occurred. ${ }^{61}$

The elections in 2000 ended the 71-year governmental hegemony of the PRI, but likewise ended the three inalienable conditions of Mexican presidentialism: a united gov-

(discussing former President Carlos Salinas' monetary situation in conjunction with that of several of his relatives).

56. See Wilson, supra note 50 , at 6-7.

57. Id.

58. Leonardo Curzio Gutiérrez, La Gobernabilidad en el Mexico Contemporario, Revista CIDOB D'AfErs INTERnaCionals, No. 40-41, 1998, at 197-199, available at http://www.cidob.org/castellano/publicaciones/Afers/40-41curzio.cfm.

59. CASTILlo, supra note 15, at 8-9 (translation by authors) (internal citations omitted).

60. Id. at 9-10.

61. See id. at 10 . 
ernment, strict discipline within the party in power, and the leadership of the President of the Republic of his own party. Mexico owed its transition from a hyper-presidentialist regime to that of a presidentialist system through a process which lasted more than ten years. ${ }^{62}$

Over time, the popularity of President Vicente Fox has waned, at least in part because, so far, he has been unsuccessful in ending, or even in mitigating, to any significant degree some of the most serious problems facing the country: poverty, corruption, an inefficient legal system and a lingering impunity enjoyed by many of those in power. ${ }^{63}$ There is no question that the political changes of recent years have contributed to changes in the structural conditions which in the past have created widespread public corruption. Moreover, recognition must be given to the efforts made both by the present and by the previous government to fight corruption at the national and international level by actively participating in developing and maintaining supranational instruments such as the Inter-American Convention Against Corruption, the Organization for Economic Co-operation and Development (OECD) Convention, the European Criminal Law Convention on Corruption and the future United Nations Convention Against Corruption. However, it is highly unlikely that corruption levels persisting in Mexican society as a whole will decrease in the immediate future, and the government will have to be watchful if it wishes to prevent the possible emergence of fresh corrupt practices or allow more virulent forms to take hold. ${ }^{64}$

Federico Reyes Heroles, President of the Consejo Directivo de Transparencia Internacional México, argues that the war against corruption should not be waged merely in a legal or administrative arena. Reyes Heroles argues that if Mexican society fails collectively to embrace responsibility for modifying its system of values, and if personal integrity is not fostered, corruption will always find an ideal breeding ground from whence it may emerge and reproduce. ${ }^{65}$

62. Id. (translation by authors) (internal citations omitted).

63. See generally LaUra Carlsen, Mexico at the Crossroads (2002), available at http://americas.irc-online.org/pdf/reports/0204mexico.pdf.

64. See generally Morris, Continuity and Change, supra note 9; see also Kimberly Ann Elliott, Corruption as an International Policy Problem, in Political Corruption: ConCEPTS AND CoNTEXTs, supra note 6, at 925.

65. Federico Reyes Heroles, Corrupcion y Valores, Crónica legislativa, No. 12, Jan.-Feb. 2000, at 90, 92, available at http://www.cddhcu.gob.mx/cronica57/contenido/ cont12/pdf12.pdf. 


\section{Soclal Representations of Public Corruption in MeXico}

\section{A. Preface to the Study}

The social phenomenon of public corruption creates interesting attitudes and perceptions among certain sections of society. The present analysis attempts to identify the representations of the phenomenon among law students and professionals in the Federal District. ${ }^{66}$ The nature of the legal community is such that it has close contact with the diverse sectors of the public administration in any country, allowing community members to form perceptions based on the practices of the public administration in the society in which they evolve. ${ }^{67}$ Finally, the Mexico City community was chosen because it rated highest (most corrupt) on Transparencia Mexicana's 2001 corruption index (during which time the study discussed in this article was conducted) ${ }^{68}$ The relevancy of this study is supported by the fact that Mexico City has demonstrated its consistency regarding its level of corruption, as indicated by the fact that it rated as the second highest state on Transparencia Mexicana's 2003 corruption index. ${ }^{69}$

The study was comprised of 294 questionnaires completed between December 3, 2001 and January 15, 2002 (inclusive). The sample consisted of a group of civil servants of the judiciary (each assigned to a court in each of the three reclusorios (detention centers) of Mexico City), a group of civil servants from two agencies of the Public Ministry of the Office of the Attorney General of Justice, a group of private attorneys, and several groups of law students from three Mexico City universities (one public and two private). Since the survey was not based on an entirely random sample, the results should be understood as guidelines and not as being representative of the entire population, although the data nonetheless provide an important indicator of the social represen-

66. A social representation is always that of the subject, whether that subject is an individual, a social or family group, or a team; in relation to another subject, it is the perception that one forms of the other. A social representation is not a duplicate of what is real or ideal, or the subjective part of the object, or the objective part of the subject; it is the relation of man to things and to other men. In this way, "social representations must be seen as an 'environment' in relation to the individual or the group; and . . . they are, in certain respects, specific to our society." Serge Moscovici, The Phenomenon of Social Representations, in Social RePresentations 3, 23 (Robert M. Farr \& Serge Moscovici eds., 1984).

67. Jean-Claude Combessie, El Método en Sociologfa 18-19 (2000).

68. See supra note 23 and accompanying text.

69. See supra note 24 and accompanying text. 
tations of the phenomenon among a key section of the legal society in Mexico City. Of the total number of people surveyed, 23.8\% were professionals and $76.2 \%$ were law students; $61.3 \%$ were employed; and the average age of the sample was twenty-four years, thirty-one for professionals and twenty-one for students.

\section{B. Analysis of the Study}

The sample of the legal community in the Federal District was asked in one of the questions to rate on a scale of one (very slight) to five (very serious) the seriousness of various problems faced by the Federal District. The responses are set out in Table 1, which ranks the problems, in order from highest to lowest, according to the total percentage each received from those surveyed who rated the particular problem as either 'serious' or 'very serious.' The Table also breaks down responses by the respondents' respective broad occupational categories. As the Table reveals, those who carry out activities in the private sector, as well as students, tended to rate the public corruption problem as more serious than those who work in the public sector. As far as raw scores received, the three problems with the highest (most serious) average ratings were public insecurity and crime (4.63), unemployment (4.36) and public corruption (4.31).

TABLE 1

\begin{tabular}{|c|c|c|c|c|}
\hline \multirow[t]{2}{*}{ Problem } & \multicolumn{4}{|c|}{$\begin{array}{c}\text { Percentage Rated 'Serious' or } \\
\text { 'Very Serious' }\end{array}$} \\
\hline & Public & Private & Students & Total \\
\hline Public insecurity and crime & $94.4 \%$ & $93.8 \%$ & $87.9 \%$ & $91.6 \%$ \\
\hline Unemployment & $90.0 \%$ & $85.0 \%$ & $82.5 \%$ & $85.5 \%$ \\
\hline Public corruption & $77.6 \%$ & $87.6 \%$ & $83.9 \%$ & $82.9 \%$ \\
\hline Economic recession & $73.0 \%$ & $77.6 \%$ & $77.2 \%$ & $76.0 \%$ \\
\hline Police forces & $72.7 \%$ & $76.0 \%$ & $73.6 \%$ & $74.0 \%$ \\
\hline $\begin{array}{l}\text { Trafficking and consumption } \\
\text { of drugs }\end{array}$ & $76.7 \%$ & $67.1 \%$ & $70.7 \%$ & $71.6 \%$ \\
\hline Access to legal aid & $50.6 \%$ & $79.7 \%$ & $68.7 \%$ & $66.1 \%$ \\
\hline Lack of housing & $59.5 \%$ & $64.6 \%$ & $68.7 \%$ & $64.7 \%$ \\
\hline Availability of legal aid & $43.8 \%$ & $75.1 \%$ & $73.5 \%$ & $64.5 \%$ \\
\hline Cost of living & $70.5 \%$ & $68.3 \%$ & $56.9 \%$ & $64.3 \%$ \\
\hline Cost of education & $52.3 \%$ & $64.6 \%$ & $56.3 \%$ & $57.3 \%$ \\
\hline Cost of health services & $52.8 \%$ & $60.3 \%$ & $58.9 \%$ & $57.3 \%$ \\
\hline $\begin{array}{l}\text { Corruption in the private } \\
\text { sector }\end{array}$ & $36.0 \%$ & $39.8 \%$ & $58.3 \%$ & $45.8 \%$ \\
\hline
\end{tabular}


Assuming that public corruption is socially perceived by the legal community of the Federal District as one of the most serious problems afflicting the Federal District and doubtless the rest of the country too - given that nearly $83 \%$ of those surveyed rated it as 'serious' or 'very serious,' above even economic recession and behind only unemployment and public insecurity and crime - it is worth questioning how to proceed in order to prevent acts of corruption in which members of the legal community intervene. Three possible mechanisms were considered in the study, each in response to its respective answer to the question of whether: 1 ) it is the public official who seeks the bribe, 2) it is the lawyer who offers the bribe, or 3 ) the sum of the bribe to be paid is already understood. Should the public official seek the bribe, it can be assumed that the act of corruption is the result of a decision made by that same official at his own risk, thus taking advantage of the power afforded by his post to award benefits or impose penalties. Should the lawyer take the initiative, it can be assumed that he may offer the bribe, again at his own risk, in order to induce a susceptible public official to be bribed into neglecting the duties of his post. If the sum of the bribe to be paid is understood simultaneously by both parties, this suggests that corrupt practices constitute a routine part of public administration and that it is not necessary to make an explicit invitation to become involved in what would otherwise be deemed as irregular conduct. This might be called the institutionalization of corruption, whereby corrupt conduct takes on maximally objective characteristics and any acknowledgement of personal responsibility is absent.

As can be observed in Table 2, the great majority of respondents consider that the mechanism whereby corruption operates consists of procedures already established, known and followed by public officials and lawyers alike. In total, nearly two-thirds of respondents said that "everyone knows how much you need to pay," while a far a lower percentage of respondents claimed that it is the lawyer who offers the bribe, and even fewer blame the official for seeking it. At first glance, this result, however, appears somewhat deceptive. It must be noted that, to a large extent, the distribution of these results may have been affected by the skewed composition of the sample, of which $76.2 \%$ were students (even though many of these student subjects were employed at the time as well). Professionals and students apparently responded in an entirely contrasting manner. While about $60 \%$ of the professionals blamed the lawyer for soliciting the bribe, approximately $75 \%$ of 
the students believed that the corruption mechanism is already established and precedes the actions of both officials and lawyers. Interestingly, the two groups both seem to rule out the possibility that it is the official who initiates the act of bribery.

TABLE 2

\begin{tabular}{|l|c|c|c|}
\hline \multirow{2}{*}{$\begin{array}{c}\text { A Lawyer Pays a Bribe } \\
\text { Because: }\end{array}$} & \multicolumn{2}{|c|}{ Status } & \multirow{2}{*}{ Total } \\
\cline { 2 - 3 } & Professional & Student & \\
\hline $\begin{array}{l}\text { The public official seeks the } \\
\text { bribe }\end{array}$ & $13.2 \%$ & $11.4 \%$ & $11.8 \%$ \\
\hline The lawyer offers the bribe & $60.3 \%$ & $12.7 \%$ & $24.0 \%$ \\
\hline $\begin{array}{l}\text { The sum to be paid is already } \\
\text { understood }\end{array}$ & $26.5 \%$ & $75.9 \%$ & $64.2 \%$ \\
\hline Total & $\mathbf{1 0 0 \%}$ & $\mathbf{1 0 0 \%}$ & $\mathbf{1 0 0 \%}$ \\
\hline
\end{tabular}

However, Table 3, which distinguishes between the public and the private employment sectors, suggests that it is the sector in which the person is employed, rather than that person's status as either student or professional, that explains the differences in perceptions of the corruption mechanism. Employees in the public sector tended to attribute a greater role to the lawyer in initiating acts of bribery, whereas the great majority of private sector employees tended to believe that corruption mechanisms are already established in the apparatus of the public administration itself. It should be highlighted, moreover, that there is also an appreciable perception in the public sector that corruption is institutionalized, particularly among students.

TABLE 3

\begin{tabular}{|l|l|c|c|c|}
\hline \multirow{2}{*}{$\begin{array}{c}\text { Sector of } \\
\text { Employment }\end{array}$} & \multirow{2}{*}{$\begin{array}{c}\text { A Lawyer Pays a } \\
\text { Bribe Because: }\end{array}$} & \multicolumn{2}{|c|}{ Status } & \multirow{2}{*}{ Total } \\
\cline { 3 - 4 } & $\begin{array}{l}\text { The public } \\
\text { official seeks } \\
\text { the bribe }\end{array}$ & $13.1 \%$ & $3.6 \%$ & $10.1 \%$ \\
\hline & $\begin{array}{l}\text { The lawyer } \\
\text { offers the } \\
\text { bribe }\end{array}$ & $65.6 \%$ & $46.4 \%$ & $59.6 \%$ \\
\hline & $\begin{array}{l}\text { The sum to be } \\
\text { paid is already } \\
\text { understood }\end{array}$ & $21.3 \%$ & $50.0 \%$ & $30.3 \%$ \\
\hline & Total & $\mathbf{1 0 0 \%}$ & $\mathbf{1 0 0 \%}$ & $\mathbf{1 0 0 \%}$ \\
\hline
\end{tabular}




\begin{tabular}{|l|l|c|c|c|}
\hline Private & $\begin{array}{l}\text { The public } \\
\text { official seeks } \\
\text { the bribe }\end{array}$ & $16.7 \%$ & $12.2 \%$ & $12.5 \%$ \\
\hline $\begin{array}{l}\text { The lawyer } \\
\text { offers the } \\
\text { bribe }\end{array}$ & $0 \%$ & $12.2 \%$ & $11.3 \%$ \\
\hline $\begin{array}{l}\text { The sum to be } \\
\text { paid is already } \\
\text { understood }\end{array}$ & $83.3 \%$ & $75.7 \%$ & $76.3 \%$ \\
\hline & Total & $100 \%$ & $100 \%$ & $100 \%$ \\
\hline
\end{tabular}

Table 4 indicates that approximately two-thirds of the sample surveyed believed that one can use a bribe to obtain efficient service from the administration with a high or very high probability of success. Again, the public and private sectors of employment differed noticeably in their responses. Although responses in both sectors recognized bribery as a highly effective mechanism, $90 \%$ of the private sector respondents rated the probability of the bribe securing efficient service as high or very high, whereas slightly fewer than half of those in the public sector gave it the same rating.

\section{TABLE 4}

\begin{tabular}{|l|c|c|c|}
\hline \multirow{2}{*}{$\begin{array}{c}\text { Probability That the Bribe } \\
\text { Will Be Successful }\end{array}$} & \multicolumn{2}{|c|}{ Sector of Employment } & \multirow{2}{*}{ Total } \\
\cline { 2 - 3 } & Public & Private & \\
\hline Very low & $16.9 \%$ & $0 \%$ & $8.9 \%$ \\
\hline Low & $9.0 \%$ & $0 \%$ & $4.7 \%$ \\
\hline Medium & $25.8 \%$ & $12.5 \%$ & $19.5 \%$ \\
\hline High & $27.0 \%$ & $36.3 \%$ & $31.4 \%$ \\
\hline Very high & $21.3 \%$ & $51.3 \%$ & $35.5 \%$ \\
\hline Total & $100 \%$ & $100 \%$ & $100 \%$ \\
\hline
\end{tabular}

Interestingly, the economic component involved in the corruption phenomenon becomes evident after comparing Tables 2, 3 and 4. As indicated by the social perception of the legal community, if the practice of bribery becomes a procedure that forms a routine part of the duties performed by a public administrative body, such bribery may be made possible by the mere existence of a high degree of impunity. Where the risk of punishment is low, so too is the cost of corruption for the public official with relatively high gain. Given that the official can exercise his decision-making powers with discretion, he may thus allow the tolerance of established irregular practices to determine the direction the lawyer takes in 
certain matters. Comparatively, again where the risk of punishment is low, the cost to the lawyer of refusing to pay a bribe (especially one that is generally considered standard industry practice) is very high, since it seemingly implies that he is virtually incompetent in the eyes of his clients. Faced with such a situation, there can hardly be any doubt as to which path the lawyer will choose, given that the typicality of the situation is unlikely to lead to professional censure, social disapproval or personal self-reproach.

This perception of the nature of corruption demonstrated in Table 4 is consistent with the fact that almost $60 \%$ of respondents said that in the last two years they had been required to pay a bribe in order to obtain a service or resolve a problem which in some way depended on the public administration of the Federal District. This social perception is also supported by the fact that about $75 \%$ of the respondents had witnessed - either indirectly or directly - acts of corruption relating to the public administration of the Federal District over the last two years. As Table 5 illustrates, only $6.5 \%$ of those who found themselves in such a situation said that they had reported the incident.

\section{TABLE 5}

\begin{tabular}{|l|c|c|c|}
\hline \multirow{2}{*}{$\begin{array}{c}\text { Responses to an Act of } \\
\text { Corruption Witnessed }\end{array}$} & \multicolumn{2}{|c|}{ Status } & \multirow{2}{*}{ Total } \\
\cline { 2 - 3 } & Professional & Student & \\
\hline Reported the incident & $2.2 \%$ & $7.6 \%$ & $6.5 \%$ \\
\hline Did not report the incident & $97.8 \%$ & $92.4 \%$ & $93.5 \%$ \\
\hline Total & $100 \%$ & $100 \%$ & $100 \%$ \\
\hline
\end{tabular}

Table 6 presents the respondents' ratings of the importance of various reasons for not reporting witnessed acts of corruption. These reasons are ranked in Table 6 according to the percentage of respondents that classified each as 'important' or 'very important.' As can be seen, the reasons that were given the highest ratings express an attitude of pessimism and resignation based on the conviction that citizens are powerless in the face of an apparatus established by the political system itself to ensure the impunity of those who perform public duties. The fact that fear of backlash ranked the highest reveals a feeling of helplessness on the part of the citizenry when contending with public power. The figures in this Table show how the perception of the corruption phenomenon is molded by the structural features of the Mexican political system. If Mexicans have learned to accept corruption, 
partly because they recognize it as a source of benefits obtainable under suitable circumstances, they are also clearly aware that, while not oppressive per se, the system created by such corruption has certain authoritarian features.

\section{TABLE 6}

\begin{tabular}{|l|c|}
\hline $\begin{array}{c}\text { Incidents of Corruption Are Not } \\
\text { Reported Because: }\end{array}$ & $\begin{array}{c}\text { Percentage Rated 'Important' or } \\
\text { Very Important' }\end{array}$ \\
\hline $\begin{array}{l}\text { There is no protection against } \\
\text { possible backlash }\end{array}$ & $76.6 \%$ \\
\hline $\begin{array}{l}\text { Those reported are able to avoid } \\
\text { punishment }\end{array}$ & $73.1 \%$ \\
\hline $\begin{array}{l}\text { Neither proper investigation nor } \\
\text { punishment are carried out }\end{array}$ & $67.4 \%$ \\
\hline Legal instruments are inefficient & $60.6 \%$ \\
\hline It is impossible to prove & $50.0 \%$ \\
\hline $\begin{array}{l}\text { Procedures are too complicated } \\
\text { Corruption is culturally accepted } \\
\text { in Mexico }\end{array}$ & $50.0 \%$ \\
\hline $\begin{array}{l}\text { The economic situation justifies } \\
\text { corruption } \\
\text { The corruption is too trivial to } \\
\text { justify reporting }\end{array}$ & $47.2 \%$ \\
\hline
\end{tabular}

One section of the questionnaire was aimed to obtain the perception of corruption as occurring in relations between businesses and the public administration of the Federal District. The first question asked respondents to rate the probability that a business would have to pay bribes in order to expand. The second question asked respondents to rate the probability that bribes would have to be paid for a contract to be awarded. Table 7 illustrates that only a small percentage - scarcely $7.5 \%$ - believed that the probability that a business must pay such bribes in order to expand is relatively low (signified by a rating of one or two on the questionnaires), whereas over $76 \%$ thought that the probability is relatively high (signified by a rating of four or five on the questionnaires). Likewise, comparatively few of the respondents surveyed believed there was a relatively low probability (signified by a rating of one or two on the questionnaires) that bribes are necessary in order for a business to obtain a contract (approximately 12\%), whereas a high percentage of respondents considered it relatively highly probable (signified by a rating of four or five on the questionnaires) that a business seeking to secure a contract would need to pay bribes (approximately 74\%). 


\section{TABLE 7}

\begin{tabular}{|l|c|l|c|}
\hline \multicolumn{2}{|c|}{$\begin{array}{c}\text { Probability That a Business } \\
\text { Must Pay Bribes in Order to } \\
\text { Expand }\end{array}$} & \multicolumn{2}{|c|}{$\begin{array}{c}\text { II. Probability That a Business } \\
\text { Must Pay Bribes in Order to } \\
\text { Secure a Contract }\end{array}$} \\
\hline & Probability & & Probability \\
\hline 5 (High Probability) & $49.8 \%$ & 5 (High Probability) & $41.3 \%$ \\
\hline 4 & $26.6 \%$ & 4 & $33.1 \%$ \\
\hline 3 & $16.0 \%$ & 3 & $13.3 \%$ \\
\hline $\mathbf{2}$ & $5.1 \%$ & 2 & $8.9 \%$ \\
\hline 1 (Low Probability) & $2.4 \%$ & 1 (Low Probability) & $3.4 \%$ \\
\hline
\end{tabular}

Given that in recent years an opposition party has governed the Federal District, it seemed appropriate to question whether the probability of resorting to bribery has increased or decreased over that period of time. Table 8 shows the responses. While some $46 \%$ thought that the probability had increased, only slightly fewer than $20 \%$ believed it had decreased. Approximately onethird believed that nothing had changed.

TABLE 8

\begin{tabular}{|l|c|c|c|c|}
\hline $\begin{array}{c}\text { Increase or } \\
\text { Decrease in } \\
\begin{array}{c}\text { Probability of } \\
\text { Resorting to } \\
\text { Bribery in Last } \\
\text { Five Years }\end{array}\end{array}$ & Frequency & Percentage & $\begin{array}{c}\text { Valid } \\
\text { Percentage }\end{array}$ & $\begin{array}{c}\text { Cumulative } \\
\text { Percentage }\end{array}$ \\
\hline Large decrease & 17 & $5.8 \%$ & $5.8 \%$ & $5.8 \%$ \\
\hline Slight decrease & 39 & $13.3 \%$ & $13.3 \%$ & $19.1 \%$ \\
\hline No change & 102 & $34.7 \%$ & $34.8 \%$ & $53.9 \%$ \\
\hline Slight increase & 80 & $27.2 \%$ & $27.3 \%$ & $81.2 \%$ \\
\hline Large increase & 55 & $18.7 \%$ & $18.8 \%$ & $100 \%$ \\
\hline Total & $\mathbf{2 9 3}$ & $\mathbf{9 9 . 7 \%}$ & $100 \%$ & \\
\hline Did not respond & 1 & $0.3 \%$ & & \\
\hline Total & 294 & $100 \%$ & & \\
\hline
\end{tabular}

The administration of Mexico's dominant party, PRI, which until recent elections exercised a political monopoly, has been frequently criticized because of the high and growing levels of corruption for which it was characterized. ${ }^{70}$ The promise of a responsible and transparent civil service has been one of the main

70. See, e.g., Morris, Continuity and Change, supra note 9, at 102-103. 
campaign issues of the leading opposition parties. ${ }^{71}$

It can be expected that the perception among citizens varies according to their partisan sympathies and loyalties. Tables 9 and 11 demonstrate, to a large extent, just this proposition. Table 9 confirms that there is in fact widespread skepticism that corruption has decreased. As indicated, it is indeed PRI-sympathizers who most consistently considered the corruption situation to have further deteriorated since that party has lost some of its political power. These PRI-sympathizers apparently believe that the opposition parties are not genuinely intent upon changing the political system for the better but rather seek total political control as well as, and more importantly, the privileges such power would afford them. Those who have recently come to power are therefore perceived as greedier than those they have replaced and also as lacking the experience to keep corruption under a certain degree of control. This hypothesis draws support from the fact that $52 \%$ of the PRI-sympathizers who contributed to this study asserted that the probability of corruption has increased, compared to $37 \%$ of the total sample that share the same view. As one might have expected, the most positive impression was found among those for whom the Democratic Revolutionary Party (PRD) (the governing party in the Federal District) is the party of preference, of whom $35 \%$ believed that the probability has decreased. Those who sympathize with the National Action Party (PAN) adopt an intermediate stance, with $50 \%$ believing that nothing has changed or that there has been some improvement. It is interesting that those who claim to have no partisan preferences are those who take the second most pessimistic stance. They are apparently skeptical of opposition parties' claims that they can downscale or eradicate corruption if elected.

71. See, e.g., id. at 112 . 


\section{TABLE 9}

\begin{tabular}{|l|r|r|r|r|r|r|}
\hline \multirow{2}{*}{$\begin{array}{c}\text { Increase or } \\
\text { Decrease in } \\
\begin{array}{c}\text { Probability of } \\
\text { Corruption in } \\
\text { Last Five Years }\end{array}\end{array}$} & \multicolumn{5}{|c|}{ Party of Preference } & \multirow{2}{*}{ Total } \\
\cline { 2 - 7 } & PAN & PRD & PRI & Other & None & \\
\hline Large decrease & $6.1 \%$ & $18.6 \%$ & $1.6 \%$ & $0 \%$ & $2.5 \%$ & $5.2 \%$ \\
\hline Slight decrease & $18.4 \%$ & $16.3 \%$ & $12.9 \%$ & $9.1 \%$ & $10.7 \%$ & $13.2 \%$ \\
\hline No change & $26.5 \%$ & $44.2 \%$ & $24.2 \%$ & $45.5 \%$ & $39.3 \%$ & $34.8 \%$ \\
\hline Slight increase & $28.6 \%$ & $18.6 \%$ & $32.3 \%$ & $27.3 \%$ & $27.9 \%$ & $27.5 \%$ \\
\hline Large increase & $20.4 \%$ & $\mathbf{2 . 3} \%$ & $29.0 \%$ & $18.2 \%$ & $19.7 \%$ & $19.2 \%$ \\
\hline Total & $\mathbf{1 0 0} \%$ & $\mathbf{1 0 0} \%$ & $\mathbf{1 0 0 \%}$ & $\mathbf{1 0 0} \%$ & $\mathbf{1 0 0 \%}$ & $\mathbf{1 0 0 \%}$ \\
\hline
\end{tabular}

On the basis of the results in the Tables studied so far, one could expect negative responses to the question of whether the government of the Federal District combats corruption effectively, and this was indeed the case. Table 10 shows that 'occasionally' was the most positive response to the aforementioned question, shared by a substantial percentage of the sample (approximately $39 \%$ ). By contrast, almost $54 \%$ believed it was 'never' or 'hardly ever' the case.

TABLE 10

\begin{tabular}{|l|c|c|c|c|}
\hline $\begin{array}{c}\text { Does the } \\
\text { Government of the } \\
\text { Federal District } \\
\begin{array}{c}\text { Combat } \\
\text { Corruption } \\
\text { Effectively? }\end{array}\end{array}$ & Frequency & Percentage & $\begin{array}{c}\text { Palid } \\
\text { Percentage }\end{array}$ & $\begin{array}{c}\text { Cumulative } \\
\text { Percentage }\end{array}$ \\
\hline Never & 47 & $16.0 \%$ & $16.3 \%$ & $16.3 \%$ \\
\hline Hardly ever & 107 & $36.4 \%$ & $37.2 \%$ & $53.5 \%$ \\
\hline Occasionally & 113 & $38.4 \%$ & $39.2 \%$ & $92.7 \%$ \\
\hline Often & 15 & $5.1 \%$ & $5.2 \%$ & $97.9 \%$ \\
\hline Always & 6 & $2.0 \%$ & $2.1 \%$ & $100 \%$ \\
\hline Total & $\mathbf{2 8 8}$ & $\mathbf{9 8 . 0 \%}$ & $100 \%$ & \\
\hline Did not respond & 6 & $2.0 \%$ & & \\
\hline Total & $\mathbf{2 9 4}$ & $\mathbf{1 0 0 \%}$ & & \\
\hline
\end{tabular}

Regarding this same question, variations similar to those in Table 9 appear once more to be based on party preference, as exhibited in Table 11. Accordingly, PRI-sympathizers gave the government of the Federal District the most negative assessment. However, scarcely one-third of those who express a preference for 
PAN concede that the Federal District government sometimes combats corruption correctly. The most positive assessment is given by PRD-sympathizers, who nonetheless tended more often towards an assessment of 'never' or 'hardly ever' than towards 'often' or 'always.' Like PRD-sympathizers, the majority of sympathizers of a party other than the three leading parties and of those who did not have a preference for any one party conceded that the Federal District government only 'occasionally' combats corruption effectively.

TABLE 11

\begin{tabular}{|c|c|c|c|c|c|c|}
\hline \multirow{2}{*}{$\begin{array}{l}\text { Does the } \\
\text { Government of the } \\
\text { Federal District } \\
\text { Combat } \\
\text { Corruption } \\
\text { Effectively? }\end{array}$} & \multicolumn{5}{|c|}{ Party of Preference } & \multirow{2}{*}{ Total } \\
\hline & PAN & PRD & PRI & Other & None & \\
\hline Never & $20.8 \%$ & $2.3 \%$ & $21.0 \%$ & $27.3 \%$ & $16.8 \%$ & $16.5 \%$ \\
\hline Hardly ever & $37.5 \%$ & $29.5 \%$ & $43.5 \%$ & $27.3 \%$ & $38.7 \%$ & $37.7 \%$ \\
\hline Occasionally & $33.3 \%$ & $45.5 \%$ & $32.3 \%$ & $45.5 \%$ & $40.3 \%$ & $38.4 \%$ \\
\hline Often & $6.3 \%$ & $13.6 \%$ & $1.6 \%$ & $0 \%$ & $4.2 \%$ & $5.3 \%$ \\
\hline Always & $2.1 \%$ & $9.1 \%$ & $1.6 \%$ & $0 \%$ & $0 \%$ & $2.1 \%$ \\
\hline Total & $100 \%$ & $100 \%$ & $100 \%$ & $100 \%$ & $100 \%$ & $100 \%$ \\
\hline
\end{tabular}

The prevailing perception of the causes of the corruption phenomenon in Mexico among the surveyed members of the legal community reveals underlying elements of the main explanations that have been offered in and by the social sciences. Table 12 shows that the four causes that were most often cited as 'important' or 'very important' were 1) the loss of values and ethical principles which has accompanied the Mexican modernization process, 2) the evolution of a culture of illegality as a response to the impunity enjoyed by public officials and social groups surrounding those in positions of power, 3) the greed or ambition of civil servants and 4) the economic inequality and poverty, which have both intensified during the modernization process. The fact that these were considered to be the most important causes of corruption is consistent with this article's characterization of the Mexican political system as being clientelistic, paternalistic and a centralizing authority. Above all, these causes are consistent with the hypothesis that the Mexican political system supports, though not necessarily on a conscious level, the institutionalization of corruption. 
TABLE 12

\begin{tabular}{|c|c|}
\hline Causes of Corruption in Mexico & $\begin{array}{c}\text { Percentage Rated 'Important' or } \\
\text { Very Important' }\end{array}$ \\
\hline $\begin{array}{c}\text { Severe loss of ethical principles in } \\
\text { society }\end{array}$ & $85.7 \%$ \\
\hline $\begin{array}{c}\text { Existence of a culture of illegality } \\
\text { where certain social groups and } \\
\text { public officials are assured of } \\
\text { impunity before the law }\end{array}$ & $82.7 \%$ \\
\hline $\begin{array}{c}\text { Greed or ambition on the part of } \\
\text { civil servants }\end{array}$ & $82.2 \%$ \\
\hline $\begin{array}{c}\text { Poverty and economic inequality } \\
\text { in society }\end{array}$ & $80.1 \%$ \\
\hline $\begin{array}{c}\text { Greed or ambition of political } \\
\text { leaders }\end{array}$ & $76.8 \%$ \\
\hline Greed or ambition of businessmen & $66.4 \%$ \\
\hline $\begin{array}{c}\text { A system of responsibilities for } \\
\text { public officials that is obsolete } \\
\text { or inadequate in the face of the } \\
\text { national reality }\end{array}$ & $66.1 \%$ \\
\hline $\begin{array}{l}\text { Low salaries of low- to medium- } \\
\text { profile civil servants }\end{array}$ & $65.3 \%$ \\
\hline $\begin{array}{l}\text { Ignorance on the part of political } \\
\text { leaders }\end{array}$ & $53.2 \%$ \\
\hline $\begin{array}{l}\text { Ignorance on the part of civil } \\
\text { servants }\end{array}$ & $46.1 \%$ \\
\hline $\begin{array}{l}\text { Low salaries of high-profile public } \\
\text { officials }\end{array}$ & $39.9 \%$ \\
\hline Lack of legislation & $36.5 \%$ \\
\hline
\end{tabular}

A final question asked to respondents which we have analyzed is that of how to rate the seriousness of a series of corruption-related failings. Unlike most of the previous questions, this one does not relate to the perception of social practices in that, here, the respondents were not obliged to admit to or imply involvement in corruption or to place blame on the processes of a system which they may have been neither responsible for nor able to avoid. Here, the respondents were asked to describe their own hierarchy of values and personal ethic.

Table 13 clearly depicts specific forms of corruption which for many are not considered serious, and are therefore seemingly somewhat excusable or permissible, because they ostensibly constitute the fulfillment of duties imposed by particular social relations networks. One example of what many respondents seemed to believe was a relatively trivial corrupt action, and therefore 
apparently somewhat permissible, was that of a public official securing a government post for a family member (39.2\% of respondents considered this form of corruption as less than 'serious'). Likewise, a situation where an individual grants an official favors or pays a sum of money and in return the official, for example, expedites an application (32.5\% of respondents considered this form of corruption as less than 'serious') or enables that individual to avoid paying a fine $(35.5 \%$ of respondents considered this form of corruption as less than 'serious') was similarly perceived by a relatively large percentage of respondents (though by a smaller percentage than in the example above) as rather trivial and thus somewhat excusable. Apparently, the most acceptable example of corruption was payment by an attorney to a security guard in order to gain access to a client (45.3\% of respondents considered this form of corruption as less than 'serious'). On the other hand, actions which were condemned as being more serious, and therefore clearly illegal and punishable, by the largest percentage of respondents included embezzlement (8.3\% of respondents considered this form of corruption as less than 'serious'), bribery for granting the release of a criminal (12.1\% of respondents considered this form of corruption as less than 'serious') and diversion of public funds $(12.2 \%$ of respondents considered this form of corruption as less than 'serious').

Not only do these responses indicate that there are degrees of tolerance with respect to corruption, but they also provide an insight into a culture of corruption in which traditional values and conventional norms are seemingly placed above the universal ethical principles at the heart of western civilization. Actions aimed at promoting a better future in this regard should include efforts to make the workings of the Mexican government more transparent and, in the process, make corruption more visible to the public. This would hopefully lead to a certain general attitude change among the public, and would ultimately promote socio-behavioral changes. 
TABLE 13

\begin{tabular}{|c|c|}
\hline \multicolumn{1}{|c|}{ Situation } & $\begin{array}{c}\text { Percentage Rated 'Serious' or } \\
\text { Very Serious' }\end{array}$ \\
\hline $\begin{array}{c}\text { A public official embezzles money } \\
\text { from the government for } \\
\text { personal use }\end{array}$ & $91.7 \%$ \\
\hline A criminal buys his freedom & $87.9 \%$ \\
\hline $\begin{array}{l}\text { A public official diverts public } \\
\text { funds, to which his post affords } \\
\text { him access, to projects or people } \\
\text { of his choice }\end{array}$ & $87.8 \%$ \\
\hline $\begin{array}{c}\text { A lawyer bribes the Public } \\
\text { Ministry }\end{array}$ & $74.6 \%$ \\
\hline $\begin{array}{l}\text { An individual pays a bribe for the } \\
\text { handling of a bureaucratic } \\
\text { matter }\end{array}$ & $67.5 \%$ \\
\hline $\begin{array}{c}\text { An individual bribes the police to } \\
\text { avoid a fine }\end{array}$ & $64.5 \%$ \\
\hline $\begin{array}{c}\text { A public official secures a } \\
\text { government post for a family } \\
\text { member }\end{array}$ & $60.8 \%$ \\
\hline $\begin{array}{c}\text { A litigator rewards the security } \\
\text { guards of a detention center in } \\
\text { order to gain speedier access to } \\
\text { his client }\end{array}$ & $54.7 \%$ \\
\hline
\end{tabular}

\section{Proposed Strategy to Fight Corruption}

During the last several years, the topics of prevention and reduction of corruption have been viewed mainly from the legal or institutional perspectives. There is no doubt that this approach is clearly necessary in the fight against corruption. However, in future years these perspectives will surely be insufficient if they are not joined by a complementary strategy which includes a fundamental change in the system of values of Mexican society. Only this type of approach, aimed at familiarizing the Mexican public with and indoctrinating it in a more ethical political culture, will truly allow for new anti-corruption measures and regulations to be accepted by Mexican society.

In that sense, this article now points out five basic components of a possible strategy against corruption: consistently sanction transgressors, involve civil society in the diagnosis of corrupt systems, concentrate prevention by repairing corrupt systems, provide incentives for reform and strengthen international cooperation against corruption. 


\section{A. Consistently Sanction Transgressors}

When a culture is imbued with deeply ingrained, widespread impunity, the only way to break away from this negative permeation is by consistently punishing, at the same time, both a significant quantity of notorious corrupt individuals and a considerable number corrupt public officials, ${ }^{72}$ regardless of the level of their position. In fact, the more visible the public official is, the better. ${ }^{73}$ In other words, to combat the generalization of a culture of impunity, it is necessary to generalize and instill a culture of legality. In order to achieve this objective, it is imperative to start with a serious revision of criminal anti-corruption legislation. This effort would be aimed at increasing the risk as much as possible both for those officials who decide to deviate from the normal legal functions of their public posts by accepting bribes and for the individuals who offer such bribes. ${ }^{74}$

\section{B. Involve Civil Society in the Diagnosis of Corrupt Systems}

Successful anti-corruption campaigns must involve the entire society. If it becomes possible to instill and motivate a culture of legality in the Mexican population, the citizens will become "fertile sources of information regarding where corruption exists." 75 Possible mechanisms that can be utilized in consulting the citizenry include (but are certainly not limited to): 1 ) conducting systematic surveys of citizens and government officials, 2) creating and maintaining civil and/or professional organizations to keep public agencies under surveillance, 3 ) creating and maintaining direct government phone lines and other paths of communication dedicated to reporting incidents of corruption, 4) instituting a mechanism for private consultations as to the legality of certain actions, 5) instituting educational programs to instruct both public officials and citizens together as to what constitutes corruption and the types of punishments generally imposed and 6) creating and maintaining village and neighborhood commissions aimed at rooting out possible corrupt persons. ${ }^{76}$

72. Klitgaard, supra note 2.

73. See id.; Robert Klitgaard, Controlling Corruption 55-57 (1988).

74. See generally Manual Prepado por Recomendacion del Consejo Económico y Social de las Naciones Unidas, in La CoRrupcion en Colombia, supra note 3, at 263, 263-302.

75. Klitgaard, supra note 2 (translation by authors).

76. $I d$. 


\section{Concentrate Prevention by Repairing Corrupt Systems}

Metaphorically, corruption can be characterized by the following formula or "Basic Equation:"

"Corruption $=$ Monopoly + Discretion - Responsibility"77

Obviously, the current Mexican legal system, including its now-existing laws and controls, has proved to be inadequate in preventing corruption. Therefore, combating public corruption in Mexico, or any other country for that matter, should begin by installing better diagnostic and disciplinary systems, implementing "vulnerability" evaluations to help anticipate and predict possible future hotbeds of corruption, ${ }^{78}$ and instituting educational programs and preventative measures in the public sector. ${ }^{79}$ Although creating incorruptible officials and citizens overnight is impossible, it may be possible to promote competency, change incentives and improve accountability in the public sector. In short, replacing the corrupt public officials alone will not remedy the situation; the legal system itself, which currently promotes (or, at least, turns a blind eye towards) corruption, must be repaired.

\section{Provide Incentives for Reform}

Governments that wish to stop the corruption of their public officials should offer more incentives to counter it..$^{80}$ These incentives should include those of an economic nature, such as pay raises, bonuses, etc. ${ }^{81}$ When typical public sector salaries fall so low that families cannot live on them, it should not come as a surprise that under such conditions corruption prospers.

\section{E. Strengthen International Cooperation Against Corruption}

Considering the current international context and the fact that in many cases corrupt officeholders escape from their countries with the proverbial fruit of their corrupt labors in tow (generally either to fiscal paradises or to other countries where extradition treaties do not exist or have no force), a strategy

77. KLITGAARD, supra note 73 , at 75 .

78. Id. at 83-85.

79. See id. at 90-91.

80 . Id. at $77-82$.

81. Id. 
against corruption will always be incomplete unless it contains a component that strengthens international cooperation..$^{82}$ In and of itself, it is vital that countries like Mexico join all possible international initiatives, in this way facilitating the exchange of information and the prosecution of these criminals across national borders.

\section{CONCLUSION}

The clientelistic, paternalistic and centralizing characteristics of authority in the Mexican political system seem to promote, or at least preserve, a hierarchy of values and personal ethics inclined to condone corruption. At least among those subjects sampled in this study, and almost certainly among most others living and working in the Mexico, governmental corruption constitutes one of the most serious problems in today's Mexican society. This study has helped to show that the general social representation of corruption in Mexico City is apparently one of institutionalization. According to this seemingly dominant social representation, acts of corruption are not merely isolated events attributable to decisions made by the officials who take advantage of their posts for personal benefit or by the lawyers who look to induce the officials into overlooking their duties. These corrupt actions have actually become systematized practices that conform to the apparent habitual and ethical norms of Mexican public administration. In effect, involvement in situations requiring bribery has become unavoidable for the lawyers who want to successfully negotiate government matters. Unfortunately, as it now stands, Mexican lawyers must conform to this corruption culture in order to be perceived as competent professionals by their clientele.

This general social representation is strengthened for many Mexico City attorneys by the all too common experience of either having had to resort to bribery in relations with public officials or having been witness to such. In accordance with this social representation, and indeed contributing to it, is the fact that these corrupt actions often go unreported (and therefore unpunished), as demonstrated by this study. This study suggests there is a widespread conviction that Federal District citizens are impotent in the face of the current legal system, which apparently assures the officials' impunity and places the citizens at risk of suffering reprisals if they seek to challenge this system.

82. See Klitgaard, supra note 2. 
Additionally, this social representation of corruption as being institutionalized is consistent with the obvious economic features of bribes. For the official, the cost of requesting or requiring a bribe is extremely low, while at the same time the cost for the lawyer of refusing to pay such a bribe is very high. Therefore, in order to break this vicious cycle of corruption, the Mexican political and legal systems must find ways to substantially raise the stakes for those public officials who wish to initiate or participate in corrupt acts. The suggestions laid out in this article can aid in this process. ${ }^{83}$ 